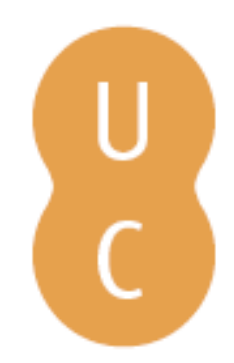

\title{
nombalina
}

\section{Difference between private and public sector accounting}

Autor(es): Wynne, Andy

Publicado por: Imprensa da Universidade de Coimbra

URL

persistente: URI:http://hdl.handle.net/10316.2/47448

DOI: $\quad$ DOl:https://doi.org/10.14195/978-989-26-1861-6_3

Accessed : $\quad$ 26-Apr-2023 12:54:30

A navegação consulta e descarregamento dos títulos inseridos nas Bibliotecas Digitais UC Digitalis, UC Pombalina e UC Impactum, pressupõem a aceitação plena e sem reservas dos Termos e Condições de Uso destas Bibliotecas Digitais, disponíveis em https://digitalis.uc.pt/pt-pt/termos.

Conforme exposto nos referidos Termos e Condições de Uso, o descarregamento de títulos de acesso restrito requer uma licença válida de autorização devendo o utilizador aceder ao(s) documento(s) a partir de um endereço de IP da instituição detentora da supramencionada licença.

Ao utilizador é apenas permitido o descarregamento para uso pessoal, pelo que o emprego do(s) título(s) descarregado(s) para outro fim, designadamente comercial, carece de autorização do respetivo autor ou editor da obra.

Na medida em que todas as obras da UC Digitalis se encontram protegidas pelo Código do Direito de Autor e Direitos Conexos e demais legislação aplicável, toda a cópia, parcial ou total, deste documento, nos casos em que é legalmente admitida, deverá conter ou fazer-se acompanhar por este aviso.

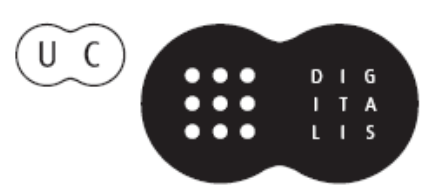



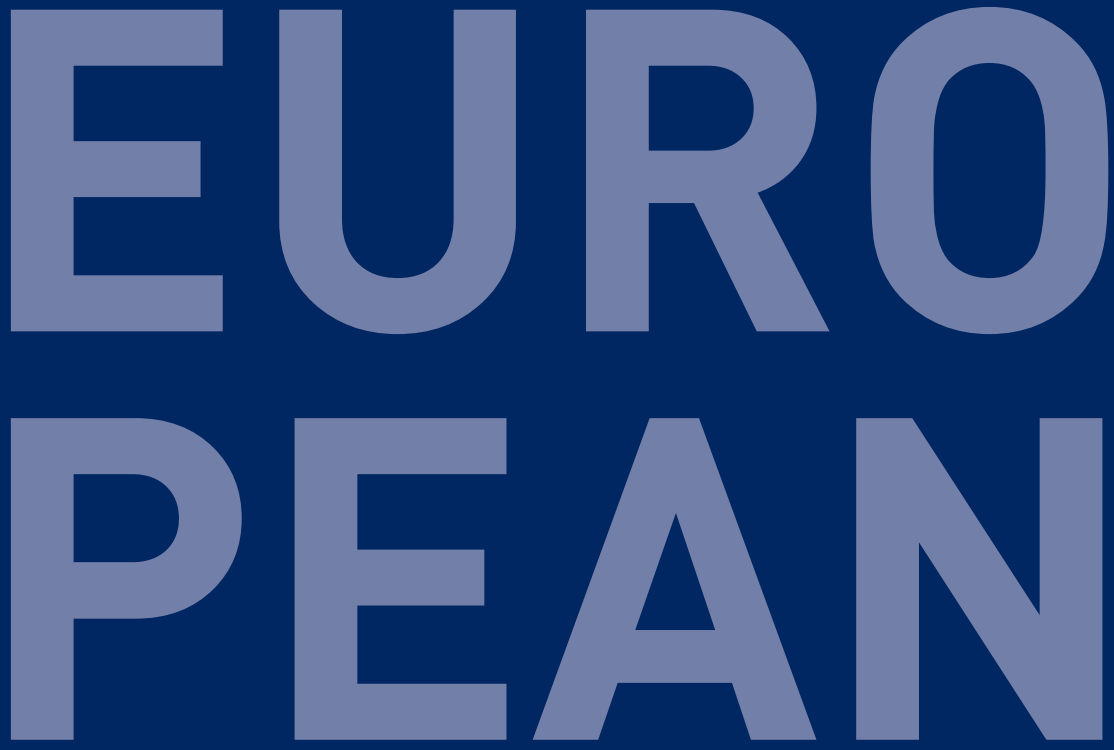

\section{PUBLIC SECTOR ACCOUNTING}

PETER C. LORSON SUSANA JORGE ELLEN HAUSTEIN

(EDS.) 


\title{
CHA P T E R 3
}

\section{DIFFERENCES BET WEEN PRIVATE AND PUBLIC SECTOR ACCOUNTING}

\author{
Andy Wynne \\ University of Leicester, $U K$ \\ amw48@le.ac.uk,andywynne@lineone.net \\ bttps://orcid.org/0000-0001-9210-9983
}

\section{SUMMARY}

International public sector accounting standards are based on the international accounting standards for the private sector. However, there are major differences between the accountabilities and financial reporting requirements of the public sector entities and those in the private sector. These differences include the objectives, different processes for generating revenues, the stakeholders and the fact that public sector entities are generally much long lasting than those in the private sector. This chapter considers these differences and the extent to which these will require changes and adaptions to private sector accounting standards to make them applicable to the public sector.

\section{KEYWORDS}

accountability, accounting standards, accrual, citizens, assets, balance sheet, budget, depreciation, financial accounting, financial reporting, financial statements, liabilities, New Public Management, private sector accounting, public sector accounting, stakeholders 


\section{Introduction}

In this chapter we consider the different approaches to financial reporting adopted in the private and the public sectors and the fundamentally different roles that they play. The chapter is based round a publication from the Government Accounting Standards Board (GASB) issued in 2006. ${ }^{1}$ These differences could perhaps lead to a questioning of whether the public sector should be adopting private sector approaches to financial reporting or, at least, emphasising the need for significant adaptions to private sector approaches to make them suitable for the public sector.

This is in stark contrast to the International Federation of Accountants (IFAC) who argue voraciously that the private sector model of financial reporting provides a comprehensive and appropriate model that should be adopted by the public sector. This is consistent with the approach of New Public Management. This argues that the public sector should adopt private sector styles of management to enable it to emulate the supposed efficiency of the private sector.

According to the GASB White Paper, the public and private sectors of the economy have:

- different purposes;

- different processes for generating revenues;

- stakeholders are starkly contrasting;

- public sector entities may often be long lasting in contrast to the often short life of private sector companies. ${ }^{2}$

This chapter provides an introduction to the different roles of financial accounting in the private sector and the public sectors. It then goes on to consider the:

1 GASB accounting and financial reporting standards for U.S. state and local governments (1984).

2 GASB (2006). These Arguments are accepted by IFAC in its Conceptual Framework. 
- key stakeholders in each sector;

- different relationships between revenue generation and the supply of goods and services in the two sectors.

This will lead to considerations of the implications for public sector accounting (PSA) reform of the fundamental differences between public sector and private sector entities.

This chapter will attempt to answer the following questions:

- What are the key differences between the public and the private sectors that may impact on their approaches to financial accounting?

- What are the key differences in the purposes of public and private sector financial statements?

- How do the processes of raising revenue differ between the public and private sectors?

- Who are the core stakeholders in the public and private sectors?

- What are the implications for the relative longevity of public sector entities?

Given the differences between the objectives of public sector and private sector accounting, how relevant are private sector approaches to accounting and how should these be adapted to ensure relevance in the public sector?

\section{Should public sector learn from the private sector?}

"Governments are fundamentally different from for-profit business enterprises in several important ways. They have different purposes, processes of generating revenues, stakeholders, budgetary obligations, and propensity for longevity."3

The above assertion contrasts with the dominant view of the last three decades, with what has been termed New Public Management. This argues that:

3 GASB (2006). 
- the free market creates wealth and prosperity for all;

- governments should be minimised;

- the residual public sector should be run efficiently (at the lowest cost) "like private sector".

There has been an on-going debate for centuries between the advocates of the two sectors and their approaches to financial reporting. The previous chapter indicated the history of change and reform in the public sector. These earlier reforms were at least partly in response to fundamental changes in the nature of the public sector from a feudal system to the adoption of parliamentary democracy.

The previous chapter also indicated that there had been a debate over the adoption of commercial double entry book-keeping by European governments from its first adoption in the mid-14th century in the City State of Genoa to the eventual adoption by the central government of Norway over 500 years later.

There has been a similar debate over the adoption of accrual accounting, or the private sector approach, by the public sector. This started in the mid-19 $9^{\text {th }}$ century when Birmingham City Council, the second largest city of England, adopted this basis for its financial statements.

Accountants trained in commercial accounting practices assume that this approach is superior to the practices adopted in the public sector. They are concerned that physical assets are not valued nor included in public sector balance sheets.

The European Union (EU) proposes to require IPSAS style accrual accounting across its member governments by 2025. But this reform has not been uniformly accepted. The Federal Audit Board in Germany, for example, has argued that accrual accounting is not suitable for the public sector and should not be a mandatory approach for all European governments. ${ }^{4}$

4 Federal Audit Board (2017). 


\section{The benefits of accrual accounting}

According to the IFAC, the information contained in financial reports that are prepared on an accrual basis of accounting is useful both for accountability and decision-making. Thus, it argues, that financial reports prepared on an accrual basis allow users to:

- assess the accountability for all resources the entity controls and the deployment of those resources;

- assess the financial position, financial performance, and cash flows of the entity; and

- make decisions about providing resources to, or doing business with, the entity. ${ }^{5}$

At a more detailed level, IFAC argues, that reporting on an accrual basis of accounting:

- shows how an entity financed its activities and met its cash requirements;

- allows users to evaluate an entity's ongoing ability to finance its activities and to meet its liabilities and commitments;

- shows the financial position of an entity and changes in financial position;

- provides an entity with the opportunity to demonstrate successful management of its resources; and

- is useful in evaluating an entity's performance in terms of its service costs, efficiency, and accomplishments. ${ }^{6}$

\section{Different purposes}

"The purpose of government is to enhance or maintain the well-being of citizens by providing public services in accordance with public policy goals." 7

\footnotetext{
5 IPSASB (2011).

6 IPSASB (2011).

7 GASB (2006).
} 
The purpose of the private sector is to earn profit. ${ }^{8}$ As a result, accrual accounting has been designed and developed to provide a comparable and consistent view on the amount of the annual profit that companies have earned. One of the key aspects of this approach is depreciation. This is designed to spread the costs of capital assets (buildings, machinery etc.) over their useful lives. This is to enable the costs of these assets to be matched with the revenue that they have helped to earn and so calculate the annual profit.

PSA, in contrast, is primarily designed to account for receipts and payments and to compare these with the agreed annual budget. It is for the government and its ministries to provide accountability for the way that it has used budgeted resources and to demonstrate that these have been used in line with the relevant laws and regulations.

Private sector companies have to sell goods or services in order to earn a profit. In the public sector, governments could maximise their 'profit' or surplus by not spending any money and so not providing the agreed services. So whilst profit provides a reasonable indicator of the extent to which a private sector company may achieve its main objective, this is not the case in the public sector.

In the public sector, financial statements are required for governments and their ministries to demonstrate accountability for the manner in which they have managed and utilised their annual budget. However, other measures, including perhaps non-financial performance indicators, are required to demonstrate how successful public sector entities have been in providing public services.

In the private sector, the annual income statement indicates the performance of the private company in achieving its key objective of making a profit. In contrast, in the public sector, the annual income statement is just a financial statement and cannot directly indicate the performance of the public sector entity in achieving its wider range of objectives. ${ }^{9}$ This is one of the reasons why Johns claimed that the

\footnotetext{
8 GASB (2006).

9 Johns (1951).
} 
introduction of private sector accounting practices into the public sector had always been a failure. ${ }^{10}$

\subsection{Redistribution of resources}

The redistribution of income and wealth, to achieve less unequal societies, is a key role of government. ${ }^{11}$ So governments generally tax the rich at a higher rate and provide a greater level of services to the poorer members of society. For this reason, in 2015, the leaders of 193 governments promised to reduce inequality as part of the United Nations Sustainable Development Goals (SDGs) ${ }^{12}$. Goal 10 is to "Reduce inequality within and among countries"13.

In contrast, if anything, private sector companies redistribute income, and so wealth, from the general public to a smaller group of shareholders (usually richer members of the public).

\subsection{Intergenerational equity?}

Those who advocate business like accounting for the public sector often claim we need to show intergenerational equity - not a concept that is used in the private sector. It is not clear why this should be an objective for the public sector, as governments do not demonstrate equity even within the current generation. As indicated above, governments re-distribute resources from tax-payers to service users.

Intergenerational equity is often used as a reason for minimising government debt (whist ignoring the assets procured with that debt).

\footnotetext{
10 IPSASB (2011).

11 United Nations (2015).

12 SDGs (2015).

13 SDGs (2015).
} 
This would have the impact of reducing the size of governments which is consistent with New Public Management and Neoliberal thinking.

\section{Generating revenues}

"[B]usinesses receive revenues from a voluntary exchange between a willing buyer and seller, governments obtain resources primarily from the involuntary payment of taxes. Taxes paid by an individual taxpayer often bear little direct relationship to the services received by that taxpayer." 14

Matching of costs and the income that is received from the goods and services that are sold is central to private sector accounting. This is the reason why depreciation is used to spread the cost of capital costs over the estimated lives of the assets.

In contrast, taxes are non-exchange transactions. There is no expectation that tax payers should receive services that are commensurate with the taxes that they have paid. Indeed, the opposite is usually the case, wealthier members of society generally pay higher rates of tax and receive a lower level of services.

Taxes are often collected for general government services and so cannot be matched with the services that they fund except that such independent activities occur in the same financial year. Taxes are generally paid into a common pool, the Consolidated Revenue Fund, from which the generality of government services are funded. There are exceptions including hypothecated taxes like the BBC (British public television channel) licence fee and vehicle licenses. The hypothecation of a tax (also known as the ring fencing or ear marking of a tax) is the dedication of the revenue from a specific tax for a particular expenditure purpose.

"In the private sector in general there exists a causal relationship: incoming services and products are exchanged for outgoing payments, and vice versa.

14 GASB (2006). 
In general we do not find such a causal relationship in the public sector, since the state and local governments receive taxes from the inhabitants, and they give many services free of charge to the inhabitants." 15

Governments aim "to provide a wide variety of services as economically as possible to beneficiaries who may or may not pay for the service."16

\section{Stakeholders}

"Citizens are not owners."17

Private sector company accounts are addressed to its shareholders. This is a discrete, relatively affluent group of people with access to expert advice. The accounts inform the shareholders on the level of the annual profit the company has earned and the viability of company as a going concern indicated by the balance sheet.

With parliamentary democracy, the government is accountable to parliament and through its members to the wider citizens (those who have the right to vote). Financial accountability consists of providing assurance that the budget and relevant laws and regulations have been complied with as required. So the report of the Auditor-General is as important as the financial statements which compare the actual payments and receipts to the budget that was previously agreed by parliament.

IFAC, in contrast, defines service recipients and resource providers (and their representatives) as the key stakeholders for public sector financial statements. ${ }^{18}$ This is a slightly different group to citizens, although many citizens will receive services from the government and pay taxes. Not all citizens are direct service recipients (except for general services like the armed forces) and resource providers may not be citizens, for example,

\footnotetext{
15 Monsen (2002).

16 Mautz (1981).

17 Mautz (1981).

18 IPSASB (2014).
} 
foreign residents or companies may pay taxes, but will not be entitled to vote in elections. In contrast many citizens may not pay taxes, at least directly. Public sector accountability is not directly related to the taxes that a person pays nor the services that they receive. It is based on the principle of one person one vote and democratic accountability to the citizenry.

\section{Subsidiary stakeholders - creditors}

"Creditors and potential creditors of governments seek information about the ability and willingness to levy taxes to finance debt repayment and the costs and obligations of those activities that could compete for those resources". ${ }^{19}$

Liquidation of private sector companies is relatively common. When this happens, those holding its debt will rely on asset sales to recover their funds. Thus banks and others holding such debts will want to see the company's balance sheet to assure themselves that their loans remain secure. Private sector debts are compared with the current value of assets to ensure that if the company goes into liquidation, the creditors will still be able to recover their money from the sale proceeds of these assets.

Major lenders can ask governments for specific information they require and so do not have to rely on the General Purpose Financial Statements (GPFSs). Public sector creditors also get assurance that their debts will be paid from the future income stream and budget surplus:

"investors have apparently relied more on the existence of the government's taxing power than on any information reported in the financial statements." 20

Loans to major governments, like those of the European Union, are generally considered to be risk free, in contrast to shares in private sector companies. This status of public sector debt does not usually vary from year to year based on the results reported in the GPFSs.

\footnotetext{
19 GASB (2006), p. 6.

20 Mautz (1981), p. 58.
} 


\section{Budgetary obligations}

"[G]overnmental budgets can be the primary method by which citizens and their elected representatives hold the government's management financially accountable." 21

Budgetary compliance is key to public sector accountability. As a result, a comparison of the actual results to the budget is essential in public sector financial statements. PSA is essentially budgetary accounting.

In the public sector, resources can only be used in amounts and ways approved by the parliament. The budget should be formally agreed by parliament before the start of the financial year. This gives authority to the government to spend in line with this budget and in compliance with the relevant laws and financial regulations.

The financial statements then indicate how the government used the allocated resources in line with the budget. The Auditor-General confirms that all spending was appropriate, in accordance with the budget and that all the relevant laws and regulations were actually complied with. Any exceptions are detailed in their annual audit report to parliament.

Public sector budgets were traditionally detailed, line-item budgets which may have extended to hundreds of pages. They indicated exactly how ministries were to spend their money with each item of expenditure making up a budget line. One aspect of New Public Management is to relax this budgetary oversight by parliament and to allow managers more freedom to decide how they should spend their budgets to achieve the stated objectives. This approach can be called performance based budgeting and the financial budgets may be accompanied by non-financial performance indicators to measure the relative success of the government spending.

In contrast, budgets, if used, are only advisory for the private sector and are usually only internal management documents. Thus budgets are not usually included as part of private sector financial statements and are not usually made public.

21 GASB (2006), p. 9. 


\section{Propensity for longevity}

Many states have lasted for at least hundreds of years - governments rarely liquidate - they may fail, but this is generally for political reasons which are rarely linked to finance.

Most private sector companies, in contrast, have a relatively short life, bankruptcy and take-overs are a normal part of business activity:

- in Britain $60 \%$ of small businesses fail in their first five years (2016 estimate);

- average listing on S\&P (US stock exchange) may only be 15 years (2012).

Due to the longevity of public sector entities/governments debtors can rely on their future income streams rather than sale of their assets under liquidation. Public sector stakeholders do not have to worry so much about the possible financial collapse of their government, nor the healthiness of its balance sheet.

\section{Inputs, outputs and financial processes in the private and public sectors}

The financial business process model of the private sector is significantly different from the that found in the public sector, as demonstrated in the figures below. The reason for the dominance of the accounting model in the private sector is that the accrual accounting model provides a universal input-output model as illustrated in the first model below: 


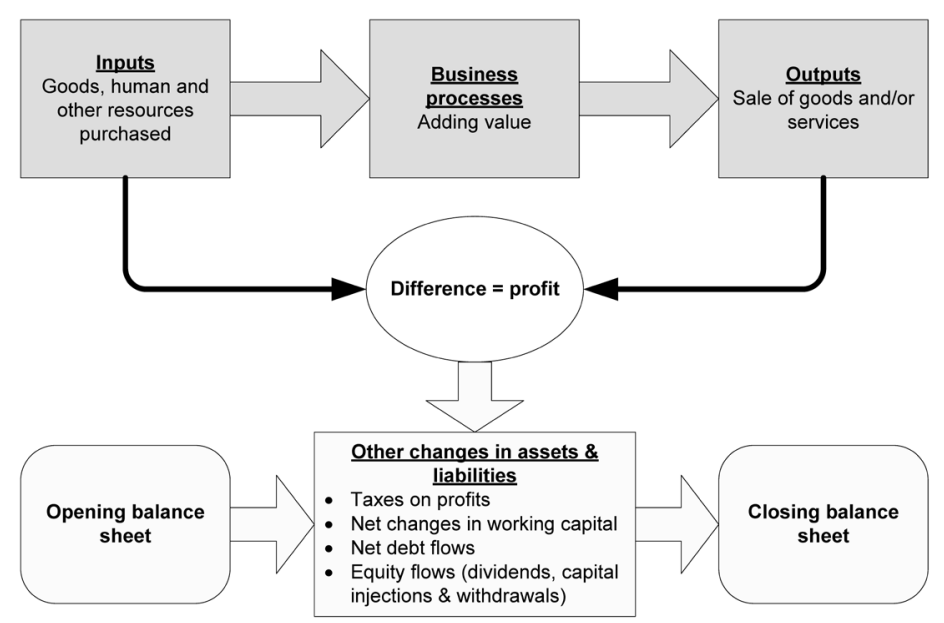

Figure 3.1: The business accounting model (Parry, 2005)

In contrast, the accounting model for governments cannot be an input output model - inputs are specified in money, but outputs are service delivery, e.g. health care, education, defence - the outputs are not "sales" 22 .
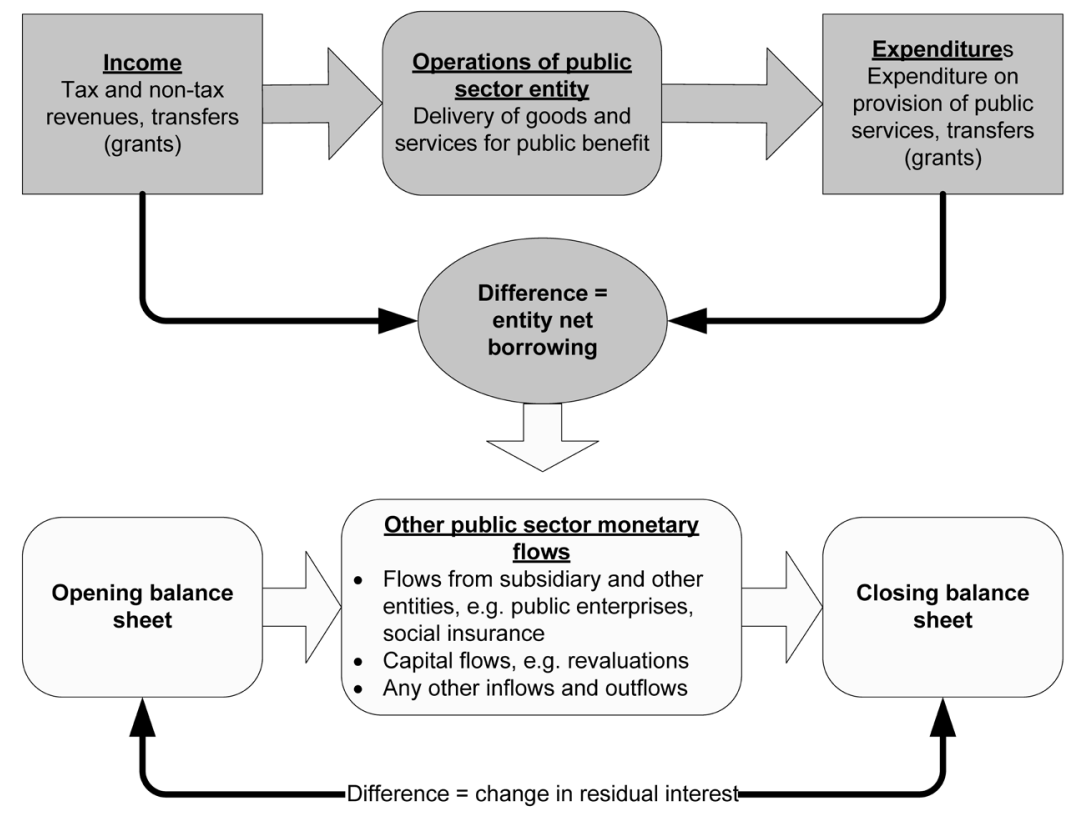

Figure 3.2: The Public Sector Accounting Model (Parry, 2005)

22 Parry (2005). 
Historically, management and control in governmental organizations has differed from the corresponding processes in business enterprises, summarized brilliantly by Rudolf Johns:

"One must distinguish sharply between the business sector on the one hand and the governmental sector on the other. In both sectors one incurs expenditures/expenses in order to produce products and services, that is, to carry out activities. The value of the products/services should always be higher than the value of that which one has to give up in order to be able to produce the products/services. An income struggle thus is found in both sectors. The respective income statements are, however, very different. In the governmental sector it is only possible to prepare a financial income statement, in the business sector a performance income statement. Within the governmental sector (the state, municipalities, counties, state governments etc.), one offers services in order to carry out public tasks. These services are not sold. If at all payments are claimed for these services, it is in the form of fees and not prices. These fees have only little or no connection to the expenses incurred to produce the services. The expenses are not covered by prices, but rather in another way, mainly through taxation. In a certain year the taxes collected are not identical to the amount used for producing the services. Societal and financial considerations and possibilities determine the size of and relationship between revenues and expenditures." (Johns (1951), p. 5; translated from German, italics in the original). ${ }^{23}$

\section{The nature of assets and liabilities}

The nature of many assets and liabilities are different in the public sector from those in the private sector. In the private sector assets are assumed to contribute to positive future cash flows. In the public sector assets are generally expected to have negative future cash flows. These will include running costs and maintenance.

23 Monsen and Oulasvirta (2008). 
In the private sector:

"Liabilities are typically incurred to obtain assets that will then be used productively in the operations of the enterprise. Through such operations the assets are intended to produce positive cash flows which, over time, permit repayment of the liabilities." 24

Thus a company may borrow money to construct a factory which will be a source of revenue and profits in future years. These profits can then be used to pay for the interest and repayments of capital on the loan. If the company fails, then the factory can be sold to pay for the remaining outstanding debts.

In contrast, in government,

"Liabilities are incurred to acquire properties that in turn add to the unit's obligations to make cash payments in the future". ${ }^{25}$

So, for example, a government may borrow money to pay for the construction of a hospital. The government will then be under some expectation, if not obligation, to pay for the running costs of the hospital in future years. So public sector assets may be a source of future costs. In addition, as noted above, governments rarely fail financially and so do not go into liquidation, their assets are rarely sold to pay for outstanding loans.

So, public sector assets are rarely used to secure loans. Future taxation will be used to repay the costs of loans and to fund the costs of the associated assets. For most governments, this future taxation will be its most significant asset. Despite this, few people argue that the right to tax should be valued and included in the government's balance sheet:

"The governmental unit's major resource, its taxing power, is not included in its balance sheet." 26

\footnotetext{
24 Mautz (1981), p. 55.

25 Mautz (1981), p. 55.

26 Mautz (1981), p. 54.
} 
In the public sector there are a range of assets for which there is no market and so it is difficult to assign a value. These include heritage assets and infrastructure assets (such as roads and railways). In the case of many heritage assets the original cost price may also not be available.

\section{Importance of public audit report}

In the private sector, the audit process adds credibility to the financial statements indicating that they were subject to independent scrutiny. The stakeholders, primarily the shareholders, are given assurance that the financial statements, including a range estimates, provide a reasonable ('true and fair') view of the level of profit that has been earned.

In the public sector the audit report is probably more important than the financial statements, in terms of public accountability:

- it indicates where there have been budgetary or other irregularities;

- it may indicate other ways in which financial management has not been optimal - performance or value for money failures.

So the publication of public sector financial statements will rarely result in coverage in the media, but the publication of the annual and other reports of the Auditor-General may lead to some press coverage.

At least under the cash basis of accounting, public sector financial statements do not include any estimates. The amount of revenue received and the amounts paid to contractors for capital contracts should be known accurately, as long as the year-end cut-off regulations have been followed properly (this should be confirmed by the auditors). In contrast, comparable figures in private sector financial statements (or under the accrual basis of accounting) are based on estimates of, for example, the useful life of an asset being used to calculate the annual depreciation. 


\section{The problem of externalities}

The government of each state has wider responsibilities than a private sector company and may have to deal with externalities created by the private sector, such as the following:

- inequality and unemployment;

- environmental pollution;

- dealing with major disasters and private sector failure;

- insurance responsibility of last resort.

As an example, the banking crisis of 2008 resulted in huge expenditures for many governments. This included supporting the banking sector and taking over some major banks including their liabilities. This had a significant impact on the finances of some governments and led to a period of austerity or reduced government expenditure which has now lasted over a decade. However, the liabilities that crystallised in 2008, had not been included in the balance sheets of the concerned governments. Even if they could have been foreseen, they could not have been estimated reliably and so could not have been included in the balance sheets.

In the private sector, in contrast, the liabilities of a company are known more accurately and so can be included in the balance sheet.

\subsection{Heritage or Community Assets}

Heritage or community assets are held and maintained principally for their contribution to knowledge and culture rather than for providing services. These may include ancient remains, museums, art galleries, national monuments, etc. These assets are held in trust for future generations. They do not have readily obtainable historic costs nor market values. In many cases they are unique and the government is not able to sell or dispose of the assets. 
Private sector companies do not hold this type of asset so we cannot look to private sector accounting practice to determine how such assets should be accounted for.

Governments should perhaps report whether these assets have been properly maintained and indicate the cost of regular maintenance if this has not been undertaken.

\subsection{Public goods}

Another set of goods which are not found in the private sector is public goods. These are goods that are both non-excludable and non-rivalrous. Individuals cannot be effectively excluded from their use and use by one individual does not reduce availability to others. Thus it is not possible to charge directly for the use of such goods as no-one can be excluded from the benefits of such assets. Many public services have at least elements of being public goods. These include, for example, the police and army. Everyone benefits from these services and no-one can be excluded from this benefit.

Other public services may also be considered to be public goods and are underprovided if they were to be only provided by the private sector. This includes public education and health. There are wider benefits to these services than just the individuals who are being educated and treated. Society at large suffers if charges are made for such services and so their take-up is reduced. Public health campaigns and inoculations benefit the whole of the public and not just a few individuals.

So public goods should be provided universally and equitably to the whole of the public. It is not clear how private sector style financial statements can demonstrate these requirements and so public goods provide another challenge to the adoption of private sector approaches to financial reporting. 


\section{Conclusion}

A leading British PSA academic summarised the differences between private and public sector accounting as follows:

The essential difference between the two sectors must be acknowledged. Public accountability is not well served by financial statements that focus on the interests of investors, and public sector assets frequently do not give rise to future cash inflows. On the other hand, fiscal control and compliance is important in the public sector, but is not in the commercial sector. Furthermore, the adoption of [private sector accounting approaches] emphasises financial accounting and external reporting to the neglect of budgeting and cost analysis that have traditionally been important aspects of public sector accountability. ${ }^{27}$

The argument about whether the public sector should adopt private sector approaches to financial reporting has been taking place for hundreds of years. There has been a largely successful push by the professional accountancy profession (IFAC, national accountancy bodies and professional firms) for the adoption of accrual accounting over the last thirty years and they have benefited handsomely from the introduction of these reforms.

However, due to the differences between private sector and public sector accountabilities, private sector approaches to accounting have to be significantly adapted to be suitable for the public sector.

Rather than adopting private sector approaches, specific additional information could be provided within public sector financial statements to meet the particular public sector accountability requirements.

\section{Bibliographic references}

BIONDI, Yuri (2012) - Should Business and Non-Business Accounting be Different? A Comparative Perspective Applied to the French Central Government Accounting Standards, Vol. 35: International Journal of Public Administration, pp. 603-619.

27 Ellwood (2003), p. 119 
DEVELOPMENT FINANCE INTERNATIONAL AND OXFAM (2017) - The Commitment To Reducing Inequality Index.

ELLWOOD, Sheila (2003) - Bridging the GAAP Across the U.K. Public Sector, Vol. 33, No. 2: Accounting and Business Research, pp. 105-21.

FEDERAL AUDIT BOARD (Bundesrechnungshof) (2017) - Special Report on the intended implementation of harmonised European Public Sector Accounting Standards (EPSAS) in the Member States of the European Union. Pursuant to Article 99 Federal Budget Code.

GASB (2006) - White Paper: Why Governmental Accounting and Financial Reporting Is and Should Be - Different, Norwalk, CT: GASB.

IPSASB (2011) - Study 14: Transition to the Accrual Basis of Accounting: Guidance for Public Sector Entities, IFAC: New York, ISBN: 1-931949-19-0; 3rd ed.

IPSASB (2014) - The Conceptual Framework For General Purpose Financial Reporting By Public Sector Entities, IFAC: New York, ISBN: 978-1-60815-192-9.

JOHNS, Rudolf (1951) - Kameralistik. Grundlagen einer erwerbswirtschaftlichen Rechnung im Kameralstil, Wiesbaden: Betriebswirtschaftlicher Verlag Dr. Th. Gabeler.

MAUTZ, Robert K. (1981) - Financial Reporting: Should Government Emulate Business?: Journal of Accountancy, pp. 53-60.

PARRY, Michael (2005) - Accrual Accounting for National Governments, Vol. V, No 2. 2005 : ICGFM Public Fund Digest.

MONSEN, Norvald (2002) - The case for cameral accounting, Financial Accountability \& Management, Vol. 18, No. 1, 2002, pp. 39-72.

MONSEN, Norvald / MONSEN, Lasse (2008) - Evolution of national government accounting: a comparative study of Finland and Norway.

MONSEN, Norvald and OULASVIRTA, Lasse (2008) - Implementing reforms in public sector accounting, Evolution of national government accounting: a comparative study of Finland and Norway, Coimbra: Imprensa da Universidade de Coimbra, ISBN: 978-989-26-0422-0.

PALLOT, June (1992) - Elements of a Theoretical Framework for Public Sector Accounting, Vol. 5 Issue 1: Accounting, Auditing \& Accountability Journal, pp. 38-59.

PARRY, Michael and HUGHES, Jesse (2019) - Accounting for Governments: from budget to audit, UK: PFM Training Limited, ISBN: 9781916037205.

UN (2015) - United Nations Sustainable Development Goals (SDGs), UN: New York.

\section{Additional readings}

FEDERAL AUDIT BOARD (Bundesrechnungshof) (2017) - Special Report on the intended implementation of harmonised European Public Sector Accounting Standards (EPSAS) in the Member States of the European Union. Pursuant to Article 99 Federal Budget Code.

GASB (2006) - White Paper: Why Governmental Accounting and Financial Reporting Is and Should Be - Different, Norwalk, CT: GASB.

IPSASB (2014) - The Conceptual Framework For General Purpose Financial Reporting By Public Sector Entities, IFAC: New York, ISBN: 978-1-60815-192-9.

MAUTZ, Robert K. (1981) - Financial Reporting: Should Government Emulate Business?: Journal of Accountancy, pp. 53-60. 


\section{Discussion topics}

- As a citizen of your country, what types of information would you find it useful to find in the financial statements for your government?

- Why do you think that some governments have adopted the accrual basis of accounting (private sector approach) in the last couple of decades?

- How important do you think equity is? Should financial statements indicate the government's success in reducing inequality in a society? How important is intergenerational equity? Can this be demonstrated in government financial statements?

- Who do you think are the people who read public sector financial statements? When did you last review the financial statements of your government? What information should public sector financial statements include?

- Why do you think that most investors consider that Government debt is a very safe investment?

- Consider the above two diagrams indicating the processes for private and public sector entities. What are the key differences that may be important for accountability and financial reporting?

- How should we account for public sector externalities? To what extent to you think that public externalities should be included as liabilities in public sector balance sheets?

- What should the starting point be for the reform of public sector financial reporting? The financial statements developed for the private sector or what refinements are needed to provide useful information at reasonable cost? 